San Jose State University

SJSU ScholarWorks

Master's Theses

Master's Theses and Graduate Research

1994

\title{
Development and evaluation of a self-concept enhancement program for students with learning disabilities
}

Deloislynn A. Boskie

San Jose State University

Follow this and additional works at: https://scholarworks.sjsu.edu/etd_theses

\section{Recommended Citation}

Boskie, Deloislynn A., "Development and evaluation of a self-concept enhancement program for students with learning disabilities" (1994). Master's Theses. 822.

DOI: https://doi.org/10.31979/etd.nur6-efvc

https://scholarworks.sjsu.edu/etd_theses/822

This Thesis is brought to you for free and open access by the Master's Theses and Graduate Research at SJSU ScholarWorks. It has been accepted for inclusion in Master's Theses by an authorized administrator of SJSU ScholarWorks. For more information, please contact scholarworks@sjsu.edu. 


\section{INFORMATION TO USERS}

This manuscript has been reproduced from the microfilm master. UMI films the text directly from the original or copy submitted. Thus, some thesis and dissertation copies are in typewriter face, while others may be from any type of computer printer.

The quality of this reproduction is dependent upon the quality of the copy submitted. Broken or indistinct print, colored or poor quality illustrations and photographs, print bleedthrough, substandard margins, and improper alignment can adversely affect reproduction.

In the unlikely event that the author did not send UMI a complete manuscript and there are missing pages, these will be noted. Also, if unauthorized copyright material had to be removed, a note will indicate the deletion.

Oversize materials (e.g., maps, drawings: 部arts) are reproduced by sectioning the original, beginning at the upper left-hand corner and continuing from left to right in equal sections with small overlaps. Each original is also photographed in one exposure and is included in reduced form at the back of the book.

Photographs included in the original manuscript have been reproduced xerographically in this copy. Higher ôuality $6^{n} \times 9^{n}$ black and white photographic prints are available for any photographs or illustrations appearing in this copy for an additional charge. Contact UMI directly to order.

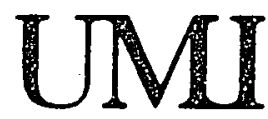

Unıversity Microfilms Internatıonal

A Bell \& Howell information Company

300 North Zeeb Road. Ann Arbor, MI 48106-1346 USA

$313 / 761.4700 \quad 800 / 521.0600$ 


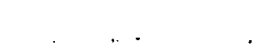


Order Number 1359005

Development and evaluation of a self-concept enhancement program for students with learning disabilities

Boskie, Deloislynn Anne, M.A.

San Jose State University, 1994

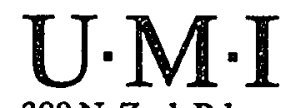


Development and Evaluation of a Self-Concept Enhancement Program for

Students with Learning Disabilities

\author{
A Thesis \\ Presented To \\ The Faculty of the Division of \\ Special Education and Rehabilitative Services \\ San Jose State University
}

In Partial Fulfillment

of the Requirements for the Degree

Master of Arts

By

Deloislynn A. Boskie

August 1994 
(c) 1994

\section{Deloislynn Anne Boskie}

ALL RIGHTS RESERVED 
APPROVED FOR THE DIVISION OF SPECIAL EDUCATION AND REHABILITATION
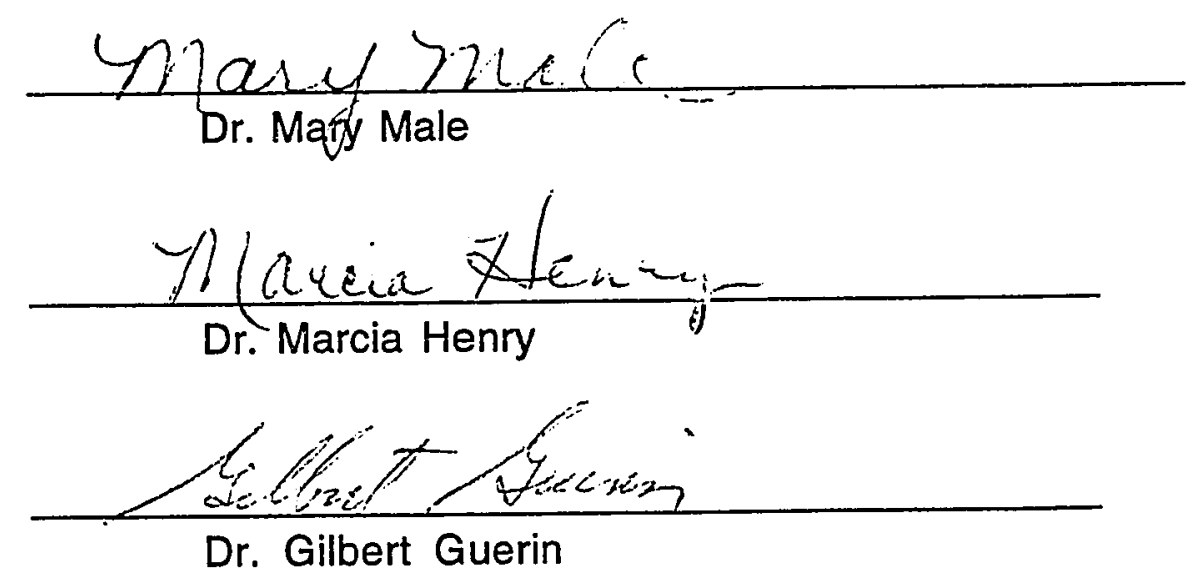

Dr. Gilbert Guerin

\section{APPROVED FOR THE UNIVERSITY}

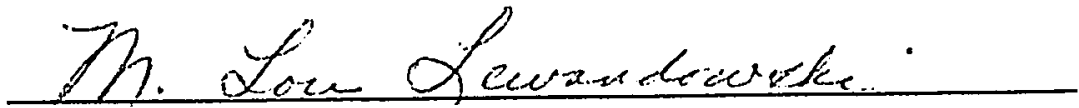




\title{
ABSTRACT \\ DEVELOPMENT AND EVALUATION OF A SELF-CONCEPT ENHANCEMENT PROGRAM FOR STUDENTS WITH LEARNING DISABILITIES
}

\author{
by Deloislynn A. Boskie
}

This thesis addresses the topic of self-concept enhancement in students with learning disabilities. It examines the development, the variables, and the activities that influence and enhance self-concept. In addition, global selfconcept and academic self-concept are studied. Twenty-two students from third through fifth grade, in two classes, participated in a six week self-concept program. All the students in the study were given a self-concept scale and an inventory of school likes and dislikes. After testing, the self-concept lessons which varied from drawing yourself to discussing goals for the future, were implemented five times a week. The results of the research indicate no significant change in self-concept in either of the two groups.

The study did not prove the effectiveness of this self-concept program; however, the study provides direction for further research and guidance in implementing this program over a longer period of time. 


\begin{abstract}
Acknowledgements
I would like to thank both my parents for their support and belief in me. It has been a long journey, and I would like to thank you both because I could not have done it without your love. Thank you, Christy, for encouraging and standing by me through all of this. Dr. Male, Dr. Guerin and Dr. Henry, thank you all for your support and encouragement throughout the editing process. I would like to dedicate this thesis to my father, Phillip Boskie, who passed away in December, 1993. I did it, Dad!
\end{abstract}




\section{TABLE OF CONTENTS}

ABSTRACT iv

ACKNOWLEDGEMENTS V v

CHAPTER
PAGE

I. INTRODUCTION

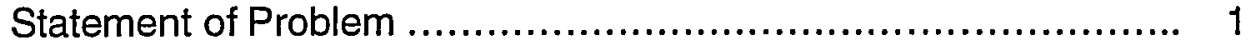

Purpose of the Study ............................................. 3

Hypothesis..................................................... 4

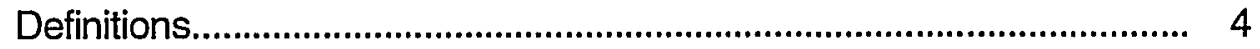

i. LITERATURE REVIEW

Development of Self-Concept .................................. 6

Definition of Self-Concept and Academic Self-Concept ........... 8

The Consistent Self ........................................... 8

Developing a Positive Self ....................................... 10

Deterrents to the Development of a Positive Self-Concept ......... 12

Self-Concept and Academic Achievement ....................... 13

The Child With Learning Disabilities ................................. 14

Lack of Success in Academic Achievement ........................ 18

The Teacher and Development of Self-Concept .................... 19

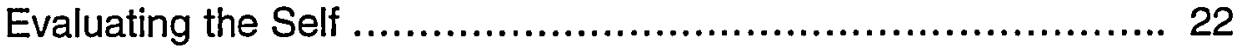

Self-Concept Enhancement in the Classroom .............................. 22

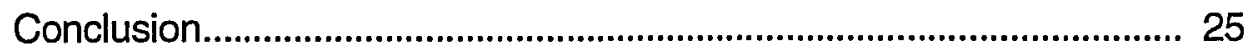




\section{METHODOLOGY}

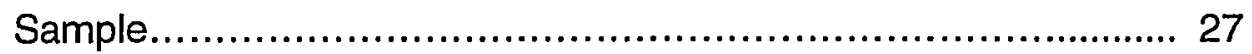

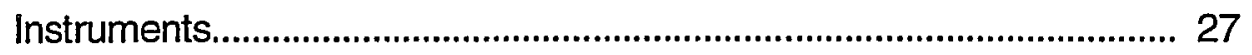

Design of the Experiment......................................................................... 28

Classroom Procedures..................................................................... 29

Research Design............................................................................ 30

Research Procedures....................................................................... 30

Design Analysis........................................................................................

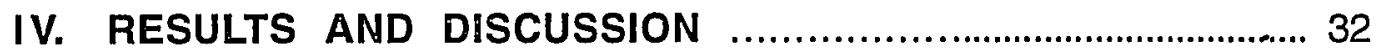

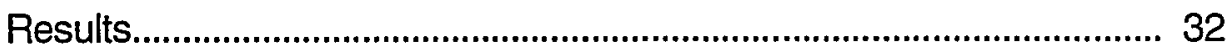

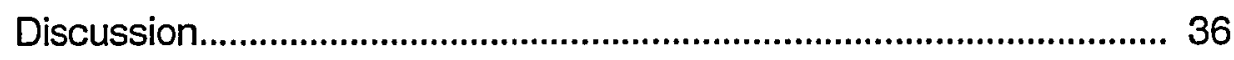

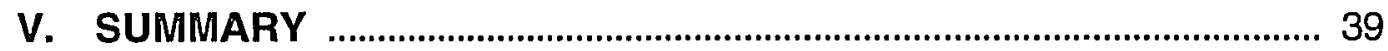

REFERENCES............................................................... 40

APPENDIX A (Piers-Harris Protocol) ............................... 44

APPENDIX B (School Likes and Dislikes) ........................... 51

APPENDIX C (Lessons) ................................................ 53

APPENDIX D (Positive Cues) .......................................... 70

APPENDIX E (Letter of Permission) ................................... 72 


\section{List of Tables}

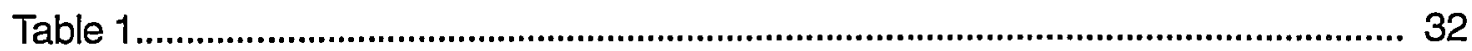

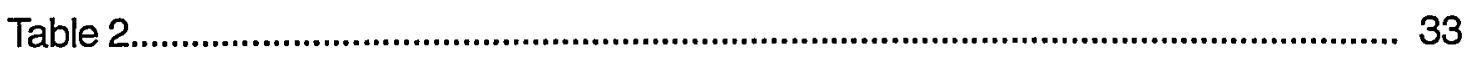

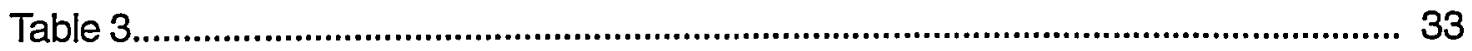

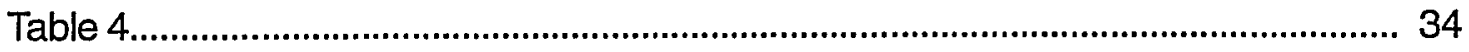

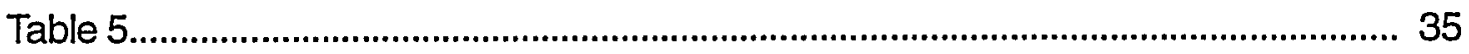

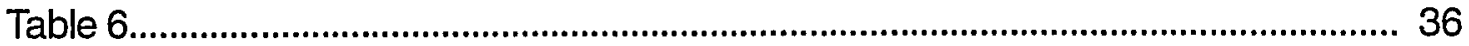




\section{CHAPTER I}

\section{Introduction}

\section{Statement of the Problem}

The importance of self-concept and its relationship to the learning disabled population is a highly relevant issue in our schools today. It may be even more pertinent today than in the past because the population of at-risk children has increased. Self-concept must be defined, and self-concept enhancement programs should be implemented and integrated into every school.

Self-concept is an individual's view or a self-perception. Hamachek (1987) defines self-concept as follows:

Self-concept refers to that particular cluster of ideas and attitudes we have about ourselves at any given moment. Another way of understanding it is to view self-concept as the organized cognitive structure of ourselves as individuals derived from the sum of all our experiences. From these experiences grow the ideas/concepts of the kind of person we see ourselves as being. (p.10)

Self-concept is the private individual within each of us that only we see. There appear to be two types of self-concept when dealing with children. One, global self-concept, (Hamachek, 1987) refers to the way we see ourselves and how others help shape those views. Two, academic self-concept, can be defined as the way a child or student views himself or. herself in a school environment.

Self-concept is shaped by significant others (e.g., teachers, parents and 
friends) in our lives. The self-concept of students is heavily influenced by those who treat them as able, valuable, and responsible, as well as by those who treat them as unable, worthless and irresponsible (Purkey \& Novak, 1984). Students need to experience success in order to develop a positive feeling about themselves. Success may occur in academic areas or nonacademic areas; successful experiences enhance a healthy self-concept. Many students in special education classes have lower self-concept than students in regular classroom settings, due to continual failures these students have experienced (Chapman, 1988). Therefore, teachers should focus on students' success and not on their failures. Positive self-concept is important to the growth of students, especially exceptional students.

As students reach school age, their self-concept is already developed and functioning. The experiences students encounter at school will be filtered through their self-concepts. As this filtering takes place, the self-concept itself is gradually altered (Purkey, Raheim \& Cage, 1983). Basically, what happens to children at school is that they experience success and failure, both of which affect their self-esteem. Learning disabled students are likely to feel less selfconfident about themselves due to negative comments, confusion, frustration and failures they have encountered in school. Therefore, teachers of students with learning disabilities must provide positive reinforcement so that children will learn that they are not complete failures, but individuals who can succeed despite their learning disabilities.

Many studies on self-concept have revealed that the children's selfperceptions are the best indicator of their school success (Purkey, 1970). The 
school should be providing programs which will help students clarify what is important to them. With the implementation of a positive self-concept program in the early years of schooling, students will take the knowledge learned about themselves and apply it to their life as they grow. Instead of sitting back and watching, the students will become active participants in their lives. By becoming active participants, students will be able to make choices themselves. Special educators of children with learning disabilities can help their students experience their own successes by providing a self-concept program which strengthens the students' self-perception. According to Canfield (1990), teachers can help strengthen their students' self-esteem and increase their chances for success in life.

Schools and school employees are in a position to help enhance and nurture students' self-concept. The potential exists within schools, but whether or not it is a reality for all learning disabled students is questionable. This research is concerned with the effects of a self-concept enhancement program.

\section{Purpose of the Study}

The purpose of this study is to test the effectiveness of a unit of self-concept activities in increasing student global self-concept and academic self-concept. Pretest and post-test scores from the Piers-Harris Children's Self-Concept Scale (CSCS) were used to measure change in the students who participated in the self-concept program. A pretest and post-test using the Informal Inventory of Likes and Dislikes in School was administered and reviewed for significant differences. The students involved in the study were third through fifth grade students with learning disabilities from two different special day classes. One 
group received the unit on self-concept development; the other did not receive the unit. The two groups were compared after the post-test using a t-test to measure group differences.

\section{Hypothesis}

1. Students with LD exposed to a self-concept program will score higher on the Piers-Harris Children's Self-Concept Scale than will students with LD not exposed to the program.

2. Students with LD exposed to a self-concept program will report a better attitude toward the school on the informal inventory of the Likes and Dislikes of School than will learning disabled students not exposed to the program.

\section{Definition of Terms}

The following terms are used in this thesis:

\section{Self-Concept}

Self-concept is defined as the total collection of attitudes, judgments, and values an individual holds with respect to his behavior, his ability, his body, his worth as a person, in short how he perceives and evaluates himself (Bryne \& Kelley, 1981, p. 271). Self- concept was measured by the Piers-Harris Children's Self-Concept Scale, a valid and reliable scale with 80 items designed for ages eight to sixteen years (Gurney, 1988).

\section{Self-Concept Enhancement Activities}

Self-concept enhancement activities are defined by Canfield and Wells (1976) as specific classroom activities that one can use to enhance the selfconcepts of students. 


\section{Activity}

An activity is any ... "learning situation in which children willingly engage, because to do so is satisfying and serves as a means of reaching a worthwhile goal desirable to the children" (Good, 1973, p. 9).

Learning Disability

Learning disabilities are defined (Lerner, 1988) as a severe discrepancy between achievement and intellectual ability in one or more of the seven areas: oral expression, listening comprehension, written expression, basic reading skills, reading comprehension, mathematics calculation, and mathematics reasoning. 
CHAPTER II

\section{Literature Review}

Investigations into the effectiveness of self-concept programs began in the 1940 's and continues today. Currently, there is limited research on the effectiveness of programs enhancing self-concept. This chapter will review literature on self-concept development, self-concept and academics, teacher self-concept, self-concept of students with LD, and enhancing self-concept in order to provide background information for the study.

\section{Development of the Self}

The initial development of self-concept involves a process of differentiation (Jersild, 1952). The infant and mother are one until birth. After birth, the child begins to explore and interact with the surrounding environment. This stage of development is known as the emergence of self. During the first stage, the formation of the self begins to go through a variety of experiences: physiological, cognitive, affective, social (Lynch, Norem-Hebeisen, \& Gergen, 1981). As a result of early experiences with the environments, the boundaries between who the child is and is not are established. More importantly, the child begins to feel a sense of value and worth as a human being. Usually, a child's language development and assertion of the self emerge at the same time. At age 2 to 5 years, the child begins to develop a stable self-concept and begins to relate to experiences through "l" and "me." As language continues to develop, so, too, does the child's self-concept.

As children approach school age, their self-concepts begin to develop. These 5 to 12-year-old children will be in the expansion of the self stage. 
During this stage, the child must adapt to new social experiences, new roles, status quo, new ways of evaluating competence and aptitudes, and new interests ( Lynch, Norem-Hebeisen, \& Gergen, 1981). These experiences will filter through the self-concept of the child and, thus, may alter the child's selfconcept.

For good or bad a child is molded by the repeated experiences in their life.

Because the self is not instinctive, but is developed as a process of experience, it is remarkably plastic, changeable and possesses infinite capacity for growth and actualization. (Purkey, 1970, p. 30)

Since World War II, researchers involved in studying the self have helped clarify the meaning of self-concepi, yet many definitions still exist. In the 1960's, self-concept research was in full force and has continued to gain momentum in the 1980's and 1990's. Many psychologists and professionals in education are furthering the research on self-concept. Psychological literature reported by Hamachek (1987) state:

Self-concept refers to that particular cluster of ideas and attitudes we have about ourselves at any given moment. Another way of understanding it is to view self-concept as the organized cognitive structure of ourselves as individuals derived from the sum of all our experiences. From these experiences grow the ideas (concepts) of the kind of person we see ourselves as being. (p. 10)

Other researchers supporting the earlier definitions of self-concept are Purkey, Raheim, and Cage who subscribe to Hamachek's definition of self-concept. These researchers described self-concept as: 
"...learner who is part of the person's "global self"--all the attitudes, opinions, and beliefs that a person holds to be true of their personal existence--that relates most directly to school achievement" (Purkey, Raheim, and Cage, 1983, p. 56). Professionals associated with education are concerned about the development of self-concept in all children. The relationships that exist between self-concept and individual growth are important for the growth of a child.

\section{Definition of Self-Concept and Academic Self-Concept}

Self-concept, the private me that only I can see (Hamachek, 1987), is affected by the significant others in our lives. Teachers, parents and others who enter into the students' lives influence their self-concepts. The self-concepts of students are heavily influenced by those who treat them as able, valuable, and responsible, as well as by those who treat them as unable, worthless and irresponsible (Purkey \& Novak, 1984). So far, the general term of self-concept has been discussed, but academic self-concept has been largely overlooked. The two concepts of self are quite different.

Self-concept can be defined in general terms as the set of beliefs people have about themselves. "Academic self-concept is a subset of general selfconcept and refers to the set of beliefs people have about themselves as students in academic or school settings" (Lynch, et al., 1981, pp. 273-274).

\section{The Consistent Self}

The person we are today is very much like the person we were yesterday and is, in all likelihood, very much like the person we will be tomorrow. "There is, for better or worse, a certain thread of consistency that weaves its way through the fabric of our personality that makes us more or less "knowable" to 
others and ourselves" (Hamachek, 1987, p. 102). Our friends and the people with whom we interact can usually foresee how we will react in a certain situation. They predict what our behaviors will be. According to Hamachek (1987), people tend to behave in ways that are consistent with their selfperceptions. Their perceptions are selective, and the primary criterion for selection is whether the experience is consistent with one's self-picture. According to Allport (1955), "thoughts and behavior have greater consistency when they relate to what we consider to be warm, central and important in our lives than they have when they are not so related" (p. 44).

If a movie were made of an individual's life, changes in the self would be seen, but at the same time, the self would be the same. How can this be true? First, you would no doubt be surprised to see the many similarities between the person you once were and the person you have become. Secondly, you would be surprised to see the many changes in your being that have occurred without your ever being aware of them (Hamachek, 1987). Nelson's follow-up study on self-consistency included 75 adolescents. He concluded that many characteristics evident in early childhood persisted into late adolescence (Hamachek, 1987).

One of the most extensive studies of consistency over time was undertaken by Kagan and Moss. The study (1962) concluded:

Many of the behaviors exhibited by the child aged six to ten, and a few during the age period three to six, were moderately good predictors of theoretically related behaviors during early adulthood. Passive withdrawal from stressful situations, dependency on family, ease-of-anger arousal, involvement, 
intellectual mastery, social interaction anxiety, sex-role identification, and pattern of sexual behavior in adulthood were related to reasonably analogous behavioral dispositions during the early school years.... These results offer strong support for the generalization that aspects of adult personality begin to take form during early childhood. (p. 141) As the movie film of our lives is viewed, consistency appears to be more apparent than changes. According to Canfield and Wells (1976), if a new experience is consistent with what you believe, it is enveloped and your Self becomes a little larger. On the other hand, if the new experience is not consistent with your Self, it is ignored or rejected. Your "glob" simply withdraws a little where the new experience hits and moves right on past it, filling itself in as though nothing has occurred. This is a wonderful protective quality. (p. 3)

\section{Developing a Positive Self}

Every experience children have and every interpretation they make of that experience influences the development of the child's self-concept, positively or negatively (Purkey, etal, 1983). Adequate persons can be defined in terms of their perception: the way they view themselves, others and their world. A healthy person: (a) has a positive view of him/herself, (b) identifies with others, (c) is open to experience, and (d) has a variety of opportunities. Maslow (1970) stated that each person has five basic needs, arranged in hierarchical order: (a) physiological needs (hunger and thirst), (b) safety needs, (c) love and belongingness needs, (d) esteem needs, (e) self-actualization needs (f) the desire for self-fulfillment, for becoming what one has the potential to become. 
According to Rogers, (1961) people en route to becoming "fully functioning" exhibit the following behaviors:

1. they move away from a self that they are not and move toward the self they really are,

2. they cease to guide their conduct in terms of what they "ought" to be or "ought" to become,

3. they move away from meeting others expectations to meeting their own expectations,

4. they move away from pleasing others and begin to be more self-directing,

5. they tend to be more accepting of themselves and able to view themselves as persons in the process of "becoming,"

6. they move toward being more open to their experiences in the sense of not having always to blot out thoughts, feelings, perceptions, and memories that might be unpleasant, and

7. they move in the direction of accepting others.

Children, as well as adults, are influenced by the significant others in their lives. Children are influenced by parents and teachers. Each child has basic needs, as Maslow's hierarchy of needs states, and these needs are fulfilled by the significant others. As Purkey (1970) concluded:

If the child's experience with important people in his/her life is good, and if she is accepted unconditionally, then she can begin to expand as a person. The development of their capacity to love is facilitated by their being loved and by being surrounded by people who love each other. A person's intelligence is increased by being exposed to an enriched and varied 
perceptual environment. (p. 31)

\section{Deterrents to the Development of a Positive Seli-Concept}

Many experts in the field of psychology and other related professions believe that adequate care provided by significant others provides positive development of the self. According to Purkey (1970), any behavior by a significant individual that causes young children to think ill of themselves, to feel inadequate, incapable, unworthy, unwanted, unloved, or unable, is crippling to the self.

Where respect and warmth are missing, where the child's questions go unanswered, where their offers to help are rejected, where his/her discipline is based on failure and punishment, where they are excluded from their parents' emotional life, and where their basic rights are abused, their self is undermined. It is vital for parents to remember the simple rule that they must have respect for and confidence in their children before their children can have self-respect or self-confidence. (pp. 33-34)

Self-concept is the way in which individuals view themselves at any given moment. The feeling and ideas we have about ourselves as learners may be directly related to our performance as learners (Hamachek, 1987). Prior to entrance into school, most children are provided care and love by their parents in order to build a foundation for a positive self. As children begin entering school, who takes over and works together with the parents? According to Hansen and Maynard (1983), school is second only to home in determining whether children's attitudes toward themselves are one of self-acceptance or self-rejection. Mistry (1960) also indicated that the school is second only to the 
home in determining an individual's attitudes of self-acceptance and selfrejection.

\section{Self-Concept and Academic Achievement}

Numerous research studies support the relationship between self-concept and academic achievement. According to Roth (1959), individuals have the definite investment to perform as they do. With all things being equal, those who do not achieve, choose not to do so (p. 262). Students who say they can not read have made the choice whether at the conscious or subconscious level. Once a student's self-perception of ability has evolved in a certain direction, the tendency seerns to be to make choices that work to reinforce the validity of the self-concept whether it be negative or positive (Hamachek, 1987).

Research indicates a relationship between high self-concept and high scholastic achievement (Purkey,1971 \&1983, Hamachek, 1987; Silvernail, 1981). Evidence also supports a relationship between low self-concept and low scholastic achievement. Purkey (1970) noted that academic success or failure appears to be deeply rooted in concepts of the self as it is in measured mental ability. Brookover (1965) concluded, from his extensive research on self-image and achievement, that assuming that human ability is the most important factor in achievement is questionable, and that the student attitudes will limit the level of achievement in school. If students feel that they have the ability to succeed or fail, either success of failure will occur depending on the students' perception of themselves. If persons have inadequate perceptions of themselves, based on their own perceptions, a wall will be created which will hinder their achievement level in school. According to Leonetti (1980), self-confidence depends on 
whether or not people believe they can succeed.

At first, it may appear that individuals with low self-concept are not intelligent because they are underachievers. On the contrary, realistic standards of excellence, elimination of excessive failure experiences, creation of conditions that maximize success, and intrinsic motivation all lead to positive self-concept and allow the child to be open to new experiences (Samuels, 1977).

A question of concern to educators is which comes first, a positive selfconcept or high academic achievement? Some evidence supports the notion that self-concept increases academic achievement, and some evidence supports the opposite. Even though it may not be possible to specify exactly which came first, good schoolwork or high self-regard, each may be mutually reinforcing to the other to the extent that a positive or negative change in one facilitates a commensurate change in order (Hamachek, 1987). Purkey (1970) suggested that: "The best evidence suggests that it is a two way street, that there is a continuous interaction between the self and academic achievement, and that each directly influences the other" (p. 23).

\section{The Child With Learning Disabilities}

The term learning disability has been defined by the National Advisory Committee for the Handicapped Children (Kirk \& Kirk, 1971):

Specific learning disability (LD) means a disorder in one or more of the basic psychological processes involved in understanding or in using language spoken or written, which may manifest itself in an imperfect ability to listen, think, speak, read, write, spell, or to do mathematical calculations. The term 
includes such conditions as perceptual handicaps, brain injury, minimal brain dysfunction, dyslexia, and developmental aphasia. The term does not include children who have learning problems which are primarily the result of visual, hearing, or motor handicaps, of mental retardation, of emotional disturbance, or of environmental, cultural or economic disadvantage. (p. 4) Since the definition of learning disabilities was published, many professionals have disagreed on the term. However, an operational definition for school districts has been implemented and refers to a significant discrepancy between measures of achievement and ability. These learning difficulties are not due to mental retardation or to major sensory, physical, emotional, or environmental factors (Mercer, Hughes \& Mercer, 1985). This operational definition provides a means of labeling students as learning disabled.

In most instances, a normal child develops at a predictable rate, but the growth of a child with LD is not so easily determined. Students with learning disabilities may have behavioral problems and emotional problems which complicate matters. According to Lerner (1981), the child whose failure to learn is accompanied by emotional problems may be the victim of a continuous cycle of failure to learn and may react emotionally to failure. Remediation must find a way to reverse this cycle: to build feelings of self-worth, to increase confidence and self-concept, and to experience success. Unfortunately, students with learning disabilities have a lower sense of themselves as compared to their achieving counterparts. How the family and significant others react to a learning disability affects perception of self. If a disability is treated with 
discomfort, shame, and secrecy, students probably will feel guilty for being learning disabled or will assume that they really are mentally retarded and psychotic (Kronick, 1981, p. 59). The treatment of the learning disabled child may become a self-fulfilling prophecy.

Factors affecting the self-concept of students with learning disabilities as stated by Kronick (1981) are as follows: The first factor affecting self-concept is the dissonant environment. A dissonant environment is an environment in which you have opposites ( black in predominantly white schools, Jews in predominantly Protestant schools, Orientals in Caucasian schools ). In this type of an environment children tend to be teased more for their differences. As a result they begin to devalue their self. According to Rosenberg (1979), "this kind of attack is particularly devastating from within" (p. 113). Learning disabled students are not only in a dissonant environment at school, but also at home. They feel different from others outside their class and home since other individuals do not share their disability nor can they comprehend their experiences. Since school settings tend to compare students to each other, many students with LD are already set up to fail. Whether it be socially or academically. Secondly, students with learning disabilities having difficulty processing social information due to their varied processing disorders. They are unable to judge how others feel, and may inaccurately judge their own abilities. The third factor which affects the self-concept of students with LD is how others perceive them. Many times the self image of a student with a learning disability is discredited when the student mentions they are in special education, when they express themself poorly, when they are clumsy or when 
they provide information. The interaction with others will cease due to the fact that their image as others perceive has been altered. Because others generalize about what is an acceptable behavior, they stereotype the student who is learning disabled. Shur (1971) suggest:

Because stereotyping involves a tendency to jump from a single cue or a small nucleus of cues of "Kind of person" being referred to, stereotyping can have an overwhelming impact on the individual, so that the person may find himself unable to sustain any alternative definition of himself. (p. 38) The final factor affecting the self-concept of students with learning disabilities is being labeled. The status as a child changes once labeled learning disabled because what is noted as characteristics of "all boy" are changed. Similar events occur in the educational setting since being learning disabled tends to be common knowledge shared. Therefore, a considerable amount of information is revealed about the student. Students also judge each other. According to Kronick (1981),

We judge ourselves and others judge us by our friends, so that other children are not eager to befriend a low-status person. Neither is the learning disabled person eager to remind others of his low status by befriending other learning disabled. As long as he avoids friendship with those having similar problems, he can cling to the illusion that he still is like everyone else. (p. 69) According to Lerner (1988), poor self-concept and low self-esteem result from years of failure and frustration. As a result, many students with learning disabilities feel little confidence in succeeding academically, so they give up easily. 
Children with learning disabilities vary in their performance and behavior (Lerner, 1988):

Ironically, the characteristics of inconsistency and unpredictability that students with learning disabilities exert may account for an occasional academic break through. However, such random moments of achievement may serve to make matters worse. For instance, the school may be convinced that he could do it if he just tried harder. Failure now may be viewed purely in terms of poor behavior and attitude rather than a learning disability. Increased impatience and blame from the teacher will intensify the student's anxiety, frustration, and confusion, which brings disastrous consequences to the ego. (pp. 477-478)

\section{Lack of Success in Academic Achievement}

Some students have trouble with school work and with their social skills, not because of low intelligence or poor hearing or even poor motivation, but because they have learned to consider themselves unable or inadequate (Hamachek,1987).

According to Eisenberg (1966):

If parents have failed to reinforce a child for good school performance or chastise him for academic misbehavior, when they convey a belief that school success bears little relationship to ultimate occupational attainment, and when they share with the child a view of school authorities as repressive agents employed by a society hostile to their own values, they provide little support for the development of achievement motivation. (p. 31) Lichter's (1982) study on girls and boys who might drop out of school 
concluded that the reasons for dropping out were not due to any specific learning failure, but rather to a continuous cycle of learning failures beginning in elementary school. As a result of this study, the significant impact on selfperceptions of young children is evident.

School success and failure seems to be determined by students' views of themselves, which are shaped by others. According to Purkey (1970), schools should follow the precept: "Every effort should be made to insure that each child entering school has a reasonable chance of victory" (p. 26). Teachers should not be quick to judge children based on others' opinions, but the teacher should begin to promote positive self growth in each child. Some children may have never met anyone who believed in them, and teachers have tremendous power to encourage children's beliefs in themselves. Teachers can make the believing last today, tomorrow and for years to come. Plant the seed of believing I can!

\section{The Teacher and Development of Self-Concept}

Teachers have a great responsibility not only to teach the academics, but to help children develop a positive, healthy self. As Moustakas (1966) declared, "every teacher wants to meet the student on a significant level, every teacher wants to feel that what they do makes a difference" (p. 45). According to Silvernail (1981), teachers play a vital role in determining a child's self-concept. The questions of how do teachers develop students' self-concept and what characteristics do these teachers employ are important and should be discussed.

Silvernail (1981) stated three principles for teachers to review when working 
to develop student's self-concept: (a) The prevention of negative self-concepts is a vital step in teaching, (b) teachers who view their students in a positive way and project favorable expectations will promote positive self-concept development, and (c) teachers must plan for the self-concept development of their students (p. 41). These are general principles teachers should keep in mind when they begin planning for a program promoting positive self-concept.

Providing a self-concept program requires teachers to diagnosis and/or assess students' self-concept. The two methods commonly used are-observation and self-reporting. When observing a student, the observer must be as objective as possible to insure that a clear picture of the student is attained. The observer will be looking at how the person looks, dresses, and the person's speech, manners, habits, expressions and their reactions in order to gather all the raw material which will enable them to draw conclusions about the individuals self-concept. As well as observing general appearance, Silvernail (1981) provided six questions that may guide teachers observations:

1. Does the student make his/her own decisions?

2. Does the student feel secure with himself/herself?

3. Does the student have a positive attitude toward learning?

4. Does the student accept himself/herself?

5. Is the student able to deal with his/her inner conflicts?

6. Does the student exhibit goal-oriented behavior (p. 43)? These guidelines will provide direction for teachers when observing a student. Self-reporting gives the teacher an instrument to assess self-concept. When using self reporting instruments, the following points should be remembered: 
1. Read the terms to very young children and students with learning disabilities.

2. Stress that there is no right or wrong answers.

3. Administer the scale in a nonthreatening manner.

4. Maintain confidentiality of the results (Silvernail, 1981, p. 47).

Once the student enters school, the responsibility to continue development is placed on the teacher. The teacher can either provided negative or positive development.

According to Canfield, (1990) effective teachers (those who promote a positive self) can be characterized in the following ways:

1. They seem to have a generally more positive view of others - students, colleagues, and administrators.

2. They see others as potentially friendly and worthy in their own rights.

3. They have a more favorable view of democratic classroom procedures.

4. They have the ability and capacity to see things as they seem to others (i.e., the ability to see things from the other person's point of view).

5. They do not see students as persons "you do things to" but rather as individuals capable of doing for themselves once they feel trusted, respected, and valued (p. 6).

Teachers who are consistent will build children rather than destroy them.

Canfield (i९9) uses a ten step model to help students become winners in life. The steps are as follows: a) Assume an attitude of 100 percent responsibility. b) Focus on the positive. c) Learn to monitor your self-talk (our thoughts). d) Use support groups in the classroom. e) Identify your strengths 
and resources. f) Clarify your vision. g) Set goals and objectives. h) Use visualization. i) Take action. j) Respond to feedback and persevere. A comment from a teacher sums up the dramatic change that can occur in a child's life due to developing a positive self-concept program in the class:

I used to think all I needed to do was to teach mathematics well. Now I teach children, not math.... The youngster who really made me understand this was Eddie. When I asked him one day why he thought he was doing so much better than last year, he replied, 'It's because I like myself now when I'm with you'. (Canfield, 1990)

\section{Evaluating the Self}

"No one, of course, can ever climb into another's skin, or see this construct we call the self, but we can infer that self in a number of ways" (Purkey, 1970, p. 58). One way is by self-reporting. Controversy over the validity and reliability of self-report has aroused mixed feelings. Some researchers agree with its use and others find it unreliable and invalid. Opposition to self-report argue that individuals only report on what they are willing and able to disclose to someone (Purkey, 1970).

\section{Self-Concept Enhancement in the Classroom}

"Self-confidence and self-esteem are often more important to school success than ability or intelligence "(Gurney, 1988, p. 82). Since self-concept seems to play a significant role in a child's academic success, it seems logical that the classrooms atmosphere would enhance the student's self-concept. Researchers have looked at the classroom environment, teachers' attitude, and actions. Teachers become the significant person once school begins. Teachers 
function as "in loco parentis" (Battle, 1982, p. 99); they share many parenting responsibilities. As reported by Battle (1982), Labenne and Green stressed the important role played in formatting a child's perception of self-worth:

Any person who is intimately involved in the administration of rewards and punishments is in a position to become a significant other; it is not merely the ability or responsibility of administering the system... that makes a teacher a significant other. Rather it is the manner in which he uses his authority that causes him to have potent impact. (p. 99)

Since teachers and parents are seen by children as significant individuals, it appears that the question left is will they have impact on enhancing the child's self-concept. According to Canfield and Wells (1976),

it is possible to change self-concepts, and it is possible for teachers to effect the changes--either way, positive or negative.... Teachers can and do affect pupils' self-concepts everyday. You have a choice over what kind of effects you will have. (p. 4)

Praising sincerely and honestly for tasks successfully completed, insuring success, reducing classroom anxiety, encouraging internal locus of control, helping students set realistic goals and demonstrating enjoyment in learning are all strategies and techniques discussed by Smith which help to improve self-concept in students with learning disabilities.

As a result of their research, Canfield and Wells (1976) determined accepting all contributions by others without judging them, establishing and maintaining a "you can do it" attitude, listening and being, in all ways, a friend are the four elements in providing a supportive classroom. 
According to Battle (1982), facilitating the development of more positive interpersonal interactions in schools is a highly desirable objective to pursue. Research by Gurney (1988) has identified classroom conditions which are conducive to self-esteem enhancement:

1. warm, accepting climate,

2. teacher positive and committed to students' progress academically, socially and emotionally,

3. classroom rules are few, democratic decision making,

4. curriculum is interesting,

5. work standard and performance are appropriate,

6. opportunity for choice,

7. pupil and teacher expectations,

8. all pupils respect each other,

9. teacher is competent, a friend and learns with the children,

10. pupils enjoy being in class (pp. 105-106).

According to Zeluff (1988), Dobson used creative writing, Jenkins incorporated peer tutoring, Hodges taught students according to the way they learn, and Greene used behavior modification to enhance LD students' learning and selfconcept. By teaching students to their strengths, students gain a sense of power and security within themselves and their self-concepts are elevated. Some strategies of teaching to strengthen include creative writing, peer tutoring, teaching to learning preferences and behavior modification.

Research conducted on the effects of classroom activities to enhance selfconcept is limited. Smith (1986) revealed the importance of research in the 
effectiveness of self-concept programs. The following letter written by a young man in her program, who wrote to his boss for a better rating, illustrates the significance of further research. He wrote:

I am a brain damage: I can use half my brain becouse of this I am very slow learner or keeping thing in my little computer when the whole of the computer would make life more easier. So in this respect I did very remarkable here buy doing the work nobody thought I could do not even my mom or dad thought.

There for becouse of this thing I do declare I should in all do respect: get the best rating. (p. 238)

Although research is limited in the area of enhancing self-concept, there are many activities which are acknowledged by professionals to be effective methods for improving self-concept. Gurney (1988) found self-concept activities to be profitable in increasing self-awareness as a part of a program to enhance self-esteem

(p. 114).

Several researchers have found a relationship between self-concept and academics. However, continual studies in self-concept with emphasis on the effects of enhancement activities should be continued.

\section{Conclusion}

Developing positive self-concept for children can be the most rewarding feeling for a teacher. As Moustakas (1966) declared (Purkey, 1970), "every teacher wants to meet the student on a significant level, every teacher wants to feel that what he does makes a difference" (p. 45). The teacher is no longer just 
looking at the child's growth in academics, but the teacher is looking at the individual's overall growth. Each student has the potential for success. When the student has failed for so long, teachers must show them the way to success. Success is not measured in accordance with others, but it is measured individually. An evaluation of a student's self-concept can be obtained by several means. The way children are taught is as important as the curriculum they are taught. 


\section{CHAPTER III}

\section{Methodology}

This study examined the effectiveness of using self-esteem activities to enhance the self-concept of students with learning disabilities.

\section{Sample}

This study was conducted with children with learning disabilities ranging in age from eight to thirteen and who are attending two elementary schools in Santa Clara County. The subjects were selected from two different elementary learning handicapped classrooms in the Alum Rock School District during the 1990 - 1991 school year. All of the children who were involved in the study were in Special Day Class (SDC) for learning handicapped students. The population included students who were identified as learning disabled (LD) as per district and state guidelines. Thirty subjects were selected for the research. Students who missed any of the sessions were excluded from the study. Four students from each class were excluded from the research due to absence from school.

\section{Instruments}

Two instruments used in this study measured student's self-concept in general and in the school settings: The Piers-Harris Children's Self-Concept Scale (CSCS) measured the students' general self-concept. CSCS consists of eighty first person declarative questions. Forty-four of the items refer to negative self-attitudes; the remainder represent a positive self-attitude. Statements such as the following appear on the scale: 1) I worry a lot, 2) I can draw well (See Appendix A). Each of the eighty statements can be circled "yes" or "no." "Yes" 
responses to positive items and "no" responses to negative items are given a value of 1 ; the reverse responses have a value of 0 . Scores can range from 0 to 80 and the higher the score, the higher the self-concept. Average scores are between the 31st and 70th percentiles or between raw scores of 46 to 60 . In the initial adminstration of the CSCS 1,183 fourth to twelfth grade students were used to standardize this self-concept measure. The results of the test indicated no sex or grade differences. The mean score overall was 51.8 with a SD of 13.9. The test-retest reliability using half of the standardized sample ranged from .71 to .77 over a four month period. The test measures six factors: behavior, intellectual status, physical appearance, anxiety, popularity, and happiness in grade $3-12$.

The second instrument created by the researcher is an informal measure of schools likes and dislikes (Appendix B). The measure has 25 items with responses of 1 to $5(1=$ always and $5=$ never $)$. The questions relate to the student's likes and dislikes in the school environment. Such items as the following appear on the questionnaire: (a) I like school, (b) No one pays attention to me at school.

Instructional material used in the research was adapted to meet the needs of the learning handicapped students. For example, in the treatment group, each student was provided a binder for journal writing and other activities that required written responses.

\section{Design of the Experiment}

This study was conducted during a six-week period at two elementary schools in the Alum Rock School District. The children were in a SDC-LH 3rd- 
5th grade classroom. The two classes which participated in the research were identified as Group A and Group B. Group A received treatment five days a week for 40 to 60 minutes a day. Group B receiving no treatment for the six week period.

Two teachers participated in the study. The instructor for Group A prepared 20 self-concept lessons for the implementation of the unit. These lessons were presented to Group A over a four weeks period. The diagram below shows the design of the study:

$\begin{array}{cccc}\text { Group } & \text { pretest } & \text { treatment } & \text { posttest } \\ \text { A } & 0 & X & 0 \\ \text { B } & 0 & & 0\end{array}$

Both teachers used personal and academic verbal reinforcements to promote positive self-concept and to encourage academic growth. The types of verbal reinforcers are included (Appendix D).

\section{Classroom Procedures}

An initial introduction to the experimental group was completed on the first day of the study. On day one, the researcher was introduced to the group of children, and explained what they were going to be learning. During the four weeks, the students shared verbally, drew, sketched, and colored.

All of the procedures and expectations were explained clearly to all the children in Group A, and the students were shown where the needed materials (paper, crayons, and markers) would be found. Certain standards were followed by the teachers and the students in Group A during the research. 
Each child was;

1. provided with an individual three ring binder.

2. expected to be responsible for his/her binder everyday including binder pick up and return.

3. expected to follow directions for each assignment given.

4. allowed to help another student who requested to be helped.

5. responsible for his/her actions. For example, no criticism of others was allowed.

6. expected to find and share the necessary materials.

7. expected to be respectful and positive to others.

\section{Research Design}

Each lesson was prepared in a progressive manner to develop the student's self-concept. All of the lessons included titles, objectives, length, day, procedures, and materials necessary. Each lesson prepared was adapted to meet the needs of the learning disabled student. A sample of the weekly lesson plan is provided in Appendix C. The students who did not participate stayed with their classroom teacher.

\section{Research Procedures}

A pre- and post-test model was used. The researcher administered the pre and post CSCS test and School Attitude questionnaire orally to Group A and Group $B$ in a two day period. The CSCS was administered, according to the directions prescribed in the examiner's manual, to the two groups in the classrooms. The questionnaire was administered orally to the subjects. The two measures were read to each group to provide equal opportunity for those 
students who had reading difficulties. All of the subjects were retested by the same examiner on measures used for the pretest. All testing results were kept in a lockeci metal filing cabinet in the teacher's classroom, and were kept confidential.

\section{Design Analysis}

\section{Examination of Pretest and Posttest}

Pre and post-test scores were gathered on each subject. A mean score representing the changes that occurred were tabulated for each pre - and posttest. A t-test was used to determine if any significant changes occurred. Based on the number of subjects who participated at posttest and the characteristics of the test score distributions, a correlation coefficient, t-test, percentage, mean, and standard deviation were used to determine significant changes in the scores

Threats to Validity

The threats to the study are as follows:

1) The study may have been conducted over too short a time to affect selfconcept.

2) Hawthorne Effect (The tendency of people to act differently because they know they are subjects in a study.)

3) Only a single treatment and control class.

4) Unequal groups at the start of the study. 


\section{CHAPTER IV \\ Results and Discussion \\ Results}

The study's results and discussion will reflect the significance of using selfesteem activities to enhance the self-concept of students with learning disabilities. To determine the effects of the self-concept enhancement activities students' self-concept levels were assessed. Assessment was completed by using the Piers-Harris Children Self-Concept Scale, and by a teacher-made School Likes and Dislikes Questionnaire.

Data was collected from the administration of the Piers-Harris Children's Self-Concept Scale. The Paired T-tests and correlation coefficients are shown in Table 1.

\section{TABLE 1}

\section{Paired T-tests and Correlation Coefficients}

\begin{tabular}{ccc} 
Test & T-value & Correlation coefficients \\
\hline Paired post t-test & 4.171 & .149 \\
& & \\
\hline
\end{tabular}

The students post-test $t$-values indicated no significance between the scores of the two groups tested. The correlation coefficients show a low positive correlation between the post-test scores of both the Group A and Group B. Further data was collected using the teacher devised Likes and Dislikes of School informal inventory.

Shown in Table 2 are the ranges and medians. 
TABLE 2

Average, Range and Median Post-test Self-Concept Scores

Groups Range Median

\begin{tabular}{lll}
\hline A & 35 & 49 \\
B & 29 & 58 \\
\hline
\end{tabular}

The scores indicate that both groups self-concept scales differed by 6 to 10 points. This variation is an indication of the variable that exist in every human being. The variation which occurred was consistent. This difference is noted. Shown in Table 3 are means, and stanines.

\section{TABLE 3}

Self-Concept Means, and Stanines
Groups
Students Pre-Mean
Post-Mean
Stanine

\begin{tabular}{lllll}
\hline A & 11 & 55 & 60 & 5.5 \\
B & 11 & 48 & 45 & 4.1 \\
\hline
\end{tabular}

The students pre-mean scores from both groups were in the normal range (46-60) on the Piers Harris Self-Concept Scale. The average stanine score is

5. Group A's post-mean score indicates a normal self-concept and Group B's post-mean score indicates a below average self-concept. After the administration of the self-concept activities, it appears as though Group A's self- 
concept had improved. Further supporting this finding is the normal reading for Group A on the stanine score and the poor reading of the stanine score for Group B. Therefore, Group A's scores indicate a positive growth in their selfconcept, and Group B shows no change.

In Table 4 and 5 students individual growth is shown.

\section{TABLE 4}

\section{Group A's Directional Sign of Pre and Post-test}

\begin{tabular}{cccc} 
Student & Pre-test & Post-test & Sign \\
\hline 1 & 36 & 49 & + \\
2 & 44 & 48 & + \\
3 & 50 & 55 & + \\
4 & 51 & 68 & + \\
5 & 54 & 61 & + \\
6 & 56 & 53 & - \\
7 & 60 & 73 & + \\
8 & 61 & 63 & + \\
9 & 61 & 56 & + \\
10 & 67 & 68 & - \\
11 & 69 & 61 & + \\
\hline
\end{tabular}

Positive change occurred in 8 out of 11 of the students who participated in the program. Therefore, $73 \%$ of the students were positively affected by the selfconcept lessons, and $27 \%$ were negatively affected. 


\section{TABLE 5}

Group B's Directional Sign of Pre and Post-test

\begin{tabular}{cccc} 
Student & Pre-test & Post-test & Sign \\
\hline 1 & 32 & 29 & - \\
2 & 38 & 49 & + \\
3 & 39 & 39 & $=$ \\
4 & 46 & 39 & - \\
5 & 48 & 49 & + \\
6 & 49 & 44 & - \\
7 & 51 & 49 & - \\
8 & 51 & 49 & - \\
9 & 55 & 57 & + \\
10 & 58 & 42 & - \\
11 & 59 & 59 & $=$ \\
\hline
\end{tabular}

The data shows a positive change in 33\% of the students in Group B, and 66\% of the students' scores were negatively changed. $22 \%$ of the students scores had no change. The scores from the students in Group A indicate a significant change in self-concept in comparison to Group B.

Shown in Table 6 are the percentage of responses that were the same, positively changed and negatively changed. 
TABLE 6

\begin{tabular}{cccccc} 
Group & \multicolumn{4}{c}{ Changes In Attitude Toward School } & \\
\hline Students & $\begin{array}{c}\text { Same } \\
\text { Response }\end{array}$ & $\begin{array}{c}\text { Positive } \\
\text { Response }\end{array}$ & $\begin{array}{c}\text { Negative } \\
\text { Response }\end{array}$ & $\begin{array}{c}\text { No } \\
\text { Response }\end{array}$ \\
\hline B & 12 & $48 \%$ & $32 \%$ & $18 \%$ & $1 \%$ \\
\hline
\end{tabular}

The experimental groups percentage scores indicate a positive change toward school. At least ten percent of a difference can be seen by comparing the Group A's positive response to that of the control group. The negative response data also reflects a decrease in comparison to the control group. Although there were positive changes, they were not significant enough to support the hypothesis.

The data collected indicates that there were no significant changes in the Group $A$ and that the changes in both groups were slight. Therefore, the scores were insignificant. The data also reveals individual differences in Group A which encouraged the positive development of the student's self-concept.

\section{Discussion}

The results of the study show there was no significant growth in the experimental group when comparing their pre and post-tests and when comparing them to the control group. Thus, their self-concepts did not seem to be affected by the program. However, the literature appears to support the belief that a student's self-concept does influence academic development. If the program implemented were continued with adjustments made in length of time, 
teacher variables, and sample size, positive changes might approach significance. Further research is need to validate the hypothesis at this time.

Different variables influenced the data and could be controlled by the researcher by structuring the study differently. The teacher variable included only one instructor who had no previous exposure to either of the study groups. Therefore, a trusting relationship was lacking and students' willingness to take risks was questionable. The length of time was also a factor. In using this program, students must be let free to expose and experience themselves outside their protective shells. Further studies should include several classroom teachers with different teaching styles and should be conducted over a one- to two year period. Teachers could observe their students' growth informally every day and keep a journal of the observations made. The method of administering the evaluation instruments to a whole group should be changed to one-on-one. Individual assessments allow the tester to observe the student while answering the questions. If the student were unclear on a question, the tester could clarify the statement. At times during the evaluations and even after reading some of the students' responses it appeared that even when students asked for clarification they did not understand what the question meant. Using the one-on-one method would allow for each student's questions to be answered further and in depth if needed. Adjustments in the study need to be made to further the use of this self-concept program.

In order for the development of self-esteem to occur, trust, respect and accountability in a students' life at school and home are needed. Unfortunately, the study did not establish the trust between the teacher and student because of 
the lack of time. The study on self-concept enhancement programs should be researched further. The development of student self-concept is crucial to development as a healthy child. 


\section{CHAPTER V}

\section{Summary}

This study was conducted to determine whether the participation in selfconcept enhancement activities by students with learning disabilities would produce a change in self-concept levels. The subjects in the study were third, fourth and fifth grade students in a public elementary school in California. The study was designed so that there was an experimental group and a control group. Two teachers were involved in the study and only one received the selfconcept activities.

The study concluded self-esteem activities can affect the self-concept of students with learning disabilities through supportive literature and informal statistical calculations. Unfortunately, the formal statistical anaylsis did not show a significant change in the self-concept of students with learning disabilities. With adjustments in the study, significant changes over a longer period could be noted.

Further research in this study is encouraged to help promote the positive impact self-esteem activities have on the self-concept of students with learning disabilities. 


\section{REFERENCES}


Allport, G. (1955). Becoming. New Haven: Yale University.

Battle, James PhD. (1982). Enhancing self-esteem and achievement. Seattle: Special Child Publications.

Brookover, W.B. (1965). The self and academic performance. In W.W. Purkey (Ed.), Self-concept and school success (pp. 14-27). Englewood, New Jersey: Prentice-Hall.

Bryne, D.E., \& Kelley, K. (1981). Humanistic theories of personalty. In D.E. Bryne \& K. Kelley (Eds.), An introduction to personality (pp. 100-104). New Jersey: Prentice-Hall.

Canfield, J. (1990). Improving students' self-esteem. Educational Leadership, pp.48-50.

Canfield, J., \& Wells, H.C. (1976). 100 ways to enhance self-concept in the classroom. Englewood Cliffs, New Jersey: Prentice-Hall.

Chapman, J.W. (1988) Learning disabled children's self-concept. Review of EducationalResearch, 55 347-371.

Coopersmith, S. (1967). The antecedents of self-esteem. San Francisco: Freeman.

Eisenberg, L. (1966) The epidemiology of reading retardation and a program for the preventive intervention. In J. Money (Ed.). The disabled reader. Baltimore: Johns Hopkins.

Good, V. (1973). Dictionary of education. New York: McGraw Hill Book Company.

Gurney, W. (1988). Self-esteem in children with special educational needs. New York: Routledge, Chapman \& Hall.

Hamachek, D.E. (1987). Encounters with the self. (3rd ed.). New York: Holt, Rinehart \& Winston.

Hansen, J., \& Maynard, P. (1983). Youth: Self-concept and behavior. Columbus, Ohio: Merrill. 
Jersild, A. (1952). In search of self. New York: Teacher's College, Columbia University.

Jourard, S. (1971). The transparent self. New York: Van Nostrand Reingold.

Kagan, J., \& Moss, H. (1962). Self-consistency: Its nature, expressions, and durability over time. In D. Hamachek (Ed.), Encounters with the self (pp. 141-145). New York: Holt, Rinehart \& Winston.

Kirk, S., \& Kirk, W. (1971). Psycholinguistic learning disabilities: Diagnosis and remediation. Urbana: University of Illinois Press.

Kronick, D. (1981). Social development of learning disabled persons. San Francisco: Josey-Bass.

Leonetti, R. (1980). Self-concept and the school child. New York: Philosophical Library.

Lerner, J. (1988). Learning disabilities. Dallas: Houghton Mifflin.

Lerner, J. (1981). Social and emotional development. In J. Lerner (Ed.), Learning disabilities (pp. 404-405). Dallas: Houghton Mifflin.

Lichter, S.O. (1982). Self-concept, academic performance, and expectations. In D. Hamachek (Ed.), Encounter with the self (pp. 260-304). New York: Holt, Rinehart \& Winston.

Lynch, M.D., Norem-Hebeisen, A.A., \& Gergen, K.L. (1981). Self-concept. Cambridge, Massachusetts: Harper \& Row.

Maslow, A.H. (1970) The self perceptual processes, and behavior: Theoretical perspectives. In D. Hamachek (Ed.), Encounters with the self (pp. 67-98). New York: Holt, Rinehart \& Winston.

Mercer, C.D., Hughes, C. \& Mercer, A.R. (1985). Learning disabilities definitions used by state education departments. Learning Disability Quarterly, 8 45-55.

Mistry, Z.D. (1960). A study of the self-picture as held by selected groups of adolescent girls, prior to, and after school leaving age. Unpublished MA thesis, University of London Library. 
Moustakas, C. (1966). The task of the teacher. In W. Purkey (Ed.), Self-concept and school achievement (p.45). Englewood Cliffs, New Jersey: PrenticeHall.

Purkey, W.W., \& Novak, J.M. (1984) Inviting school success (2nd ed.). Belmont, CA: Wadsworth.

Purkey, W.W., Raheim, A. \& Cage, B.N. (1983). Self- concept as a learner: An overlooked part of self-concept theory. Humanistic Education and Development, 22 55-57.

Purkey, W.W., (1970). Self concept and school achievement. Englewood Cliff, New Jersey: Prentice-Hall.

Rogers, C.R. (1961). Client-centered therapy. Boston: Houghton Mifflin.

Rosenberg, M. (1979). Conceiving the self. New York: Basic Books.

Roth, R.M. (1959). Self-concept, academic performance, and expectations. In D. Hamachek (Ed.), Encounters with the self. (pp. 262-263). New York: Holt, Rinehart \& Winston.

Samuels, S. (1977). Enhancing self-concept in early childhood. New York: Human Sciences Press.

Shur, E.M. (1971). Labeling deviant behavior: It sociological implications. New York: Harper \& Row.

Silvernail, D.L. (1981). Developing positive student self-concept. Washington, D.C.: NEA.

Smith, G.B. (1986). Self-concept and the learning disabled child. Reading. Writing, and Learning Disabilities, 2 237-241.

Zeluff, K.A. (1988). Improving student performance. Academic Therapy, 24:1 95-98. 
APPENDIX A 


\title{
PLEASE NOTE
}

\begin{abstract}
Sopyrighted materials in this document have not been filmed at the request of the author. They are available for consultation, however, in the author's university 1ibrary.
\end{abstract}

$$
\text { 45-50 }
$$

\section{University Microfilms International}


APPENDIX B 


\section{Inventory of School Likes and Dislikes}

1- always 2- often 3- sometimes 4- rarely 5- never

1. My teacher helps me.

2. I like school.

3. Kids pick on me.

4. School days are good days.

5. I am glad to be at school.

6. I hate school.

7. I have a lot of friends in school.

8. I like math.

9. I like my teacher.

10. 1 like myself.

11. I like reading.

12. I siop when things get hard.

13. I like science.

14. I like art.

15. 1 like playing by myself.

16. My teacher is nice.

17. I like recess.

18. I like the way I look.

19. I am happy.

20. No one pays attention to me at school.

21. My teacher really cares about me.

22. I am unhappy at school.

23. I am smart.

24. My classmates like me.

25. I know how to be good.
12345

12345

12345

123345

12345

12345

$\begin{array}{lllll}1 & 2 & 3 & 4 & 5\end{array}$

123345

12345

$\begin{array}{lllll}1 & 2 & 3 & 4 & 5\end{array}$

$\begin{array}{lllll}1 & 2 & 3 & 4 & 5\end{array}$

$\begin{array}{lllll}1 & 2 & 3 & 4 & 5\end{array}$

12345

$\begin{array}{lllll}1 & 2 & 3 & 4 & 5\end{array}$

12345

12345

12345

12345

12345

12345

12345

12345

12345

12345

12345 


\section{APPENDIX C}




\section{LESSON PLAN}

ACTIVITY: Daily Journal Writing

OBJECTIVE: To provide students with the opportunity to record what they have earned about themselves.

LENGTH OF LESSON: 5 to 10 minutes

DAYS: Monday, Wednesday, and Friday.

\section{PROCEDURES:}

1. At the beginning of each class session each student will be given a binder for their journal entries.

2. After the folders have been passed out a daily topic will be written on the chalkboard.

3. The students will be asked to respond to the daily topic on the board by writing and illustrating their responses.

4. After the students have completed the assignment their folders will be collected by a classroom helper.

5. Journal entries will not be shared unless students wish to share their responses. At the end of each class session students will be asked to share what happened on a volunteer basis.

\section{JOURNAL TOPICS:}

-I feel good when.... -I wish my teacher.... -l like myself because.... -My classmates think $1 . .$. . -If I want to, I can....

-The one thing I most want to accomplish is....

MATERIALS: Journal binders and pencils
-If I could have one wish it would be....

-I get angry when....

-People who expect alot from me make me feel....

-The best thing about being me is.... -The worst thing about being me is.... -I feel most important when I.... 


\section{LESSON PLAN}

ACTIVITY: The trust walk

OBJECTIVE: To encourage and develop trust among their classmates.

LENGTH OF LESSON: 10 to 20 minutes

D AY: Monday, Wednesday or Friday

\section{PROCEDURES:}

1. Each student will pick a partner they feel friendly with or close to.

2. After the students have partners the teacher will explain that the partners will be going on a walk and that one person will be blind folded and the other person will be the guide.

3. Then the students will be asked to choose who will be the guide and who will be guided.

4. The roles of the partners will be explained at this time. The guide's job is to make sure that their partner is safe at all times - ie. , he/she doesn't bump or fall in to anything.

5. The teacher will remind the guides to allow their partners to experience what objects feel like ie., a water fountain, soft carpet, window, etc.

6. After ten to fifteen minutes at the sound of a whistle or a signal to have partners change roles.

7. Once everyone has been guided around a discussion of the experience will follow. The following questions will used to prop discussion:

- Were you able to trust your partner with your eyes closed?

- Did you open your eyes at any time?

- Did you find it easier following or leading? What was easy or hard about it?

- Did you enjoy the exercise? What did you enjoy about it?

MATERIAL: blindfolds 


\section{LESSON PLAN}

ACTIVITY: The Magic Box

OBJECTIVE: To help students see that they are unique and special individuals.

LENGTH OF LESSON: 30 minutes

DAYS: Monday, Wednesday, and Friday PROCEDURES:

1. The teacher will ask the class to a circle and then ask the students, "Who do you think is the most special person in the whole world?" Give each child a chance to respond to the question with their individual answers. After the students have responded continue by asking them this question, "Well, I have a magic box with me today, and each of you will have a change to look inside and discover the most important person in the world." (Inside the box is a mirror).

2. The magic box will be passed around so that each student will be able to see the most important person.

3. After all the children have had their turns, ask the group who the most important person was. After each child has had an opportunity to say "me," explain that the box is valuable because it shows that each of them is a special person.

4. Discuss with the class how it is possible for everyone to be the special one.

\section{MATERIALS:}

chairs magic box with a mirror inside of the box 


\section{LESSON PLAN}

ACTIVITY: Words that describe Me

OBJECTIVE: To encourage the students to set goals and do somethings about them.

LENGTH: 40 to 50 minutes

DAY: Monday, Wednesday or Friday

PROCEDURES:

1. Explain to the students we are going to be working on "Me".

2. The students will be asked to write down three words that describe themselves. For example, it can be how you look, feel, personality or things that make you different.

3. When the students have finished ask them to turn the paper over and write three words they wish described themselves. For example, they help people in distress.

4. The students will need to give specific behaviors for one of the words on the wish list. After the students have listed specific behaviors for the one word they chose, ask each student to use that word as a goal. For example, If Lynn wants to be kind she will start practicing some of those behaviors she has listed and can begin to look for opportunities to be kind.

\section{MATERIAL:}

$16-2081 / 2 \times 11$ folder paper 


\section{LESSON PLAN}

ACTIVITY: Collage of self

OBJECTIVE: To encourage the unique individuals we are.

LENGTH OF LESSON: 40 to 60 minutes

DAYS: Monday, Wednesday, or Friday

\section{PROCEDURES:}

1. Today we are going to make a collage entitled "Me."

2. The teacher will hand out a $12 " \times 18$ " piece of construction paper to each student.

3. Next, the students will be asked to cut out pictures, words, and symbols that represent what they like to do, things they own, places they've been, people they admire and more.

4. After the students have cut out pictures, words and symbols, the students will be asked to paste all their cut-outs on the construction paper.

5. After everyone has finished their collage the teacher will collect them and place them on display in their classroom.

\section{MATERIALS:}

15 pieces - 12 " $\times 18^{\prime \prime}$ color construction paper

15 - scissors

glue

varies magazines 


\section{LESSON PLAN}

ACTIVITY: If I could be....

OBJECTIVE: To help students clarify who they are, what they want to be and What they want to do.

LENGTH OF LESSON : 30 to 40 minutes

DAYS: Monday, Wednesday or Friday PROCEDURES:

1. Today we are going to be working with a partner answering questions like these: If I could be any animal, l'd be a tiger because they are smart. You and your partner will answer the questions on the sheet I will be handing out. After you have written your answers you will discuss your answers with your partner.

2. The teacher will hand out the papers with the questions to each student, and the students can then begin answering the questions.

3. After the students have completed the assignment the papers will be picked up, and anyone willing to share some of their thoughts about the activity can share them.

\section{MATERIALS:}

15 worksheet - If I could be.... pencils 


\section{IF | COULD BE..}

1. If I could be any animal, l'd be $a(n) \_$because

2. If I could be a flower, l'd be a(n) because

3. If I could be a piece of furniture, l'd be a(n) because

4. If I could be a musical instrument, l'd be a(n) because

5. If I could be a car, l'd be a(n)

because

6. If I could be a state, l'd be because

7. If I could be a game, l'd be because

8. If I could be a movie, l'd be because

9. If I could be a food, l'd be because 10. If I could be any color, l'd be because

11. If you could be anything, l'd be because 


\section{LESSON PLAN}

ACTIVITY: Body Tracing

OBJECTIVE: To develop insight into each individuals uniqueness.

LENGTH OF LESSON: 30 to 40 minutes

DAY: Monday, Wednesday and/or Friday (2 day lesson)

\section{PROCEDURES:}

1. The students will be asked to form a group of two. Then each student will be given a large piece of butcher paper.

2. After the paper has been passed out each student will lie down on the paper while their partner traces an outline of his body. Once both students have finished outlining, they may begin coloring in their figures of themselves. Once the self-portraits are colored the students will cut them out.

3. The teacher will display the self-portraits in the classroom.

\section{MATERIALS:}

$16-20$ pieces of butcher paper

$16-20$ pencils

8- 10 boxes of crayons and markers

$16-20$ pairs of scissors 


\section{LESSON PLAN}

ACTIVITY: IALAC (1-ah-lack)

OBJECTIVE: To illustrate how one's self-concept can be destroyed by others.

\section{LENGTH OF LESSON: 2 Days}

DAYS: Monday, Wednesday or Friday

\section{PROCEDURES:}

1. The teacher will hold up a large piece of paper with IALAC boldly written on it.

2. After the teacher has gained the students attention she will explain that everyone carries an invisible IALAC sign around with them all of the time and wherever they go. Ask the students if they know what IALAC means. Allow for the students to take guesses. After a couple of minutes the teacher will explain what IALAC means (I am lovable and capable).

3. The teacher will explain that this is our self-concept or how we feel about ourselves. Then the instructor will discuss the fact that everyone's sign is determined by how others treat us. For example if somebody is nasty to us, teases us, puts us down, rejects us, hits us, then a piece of our IALAC sign is destroyed- a piece of the IALAC introduced should be torn at this time.

4. Now the students are ready for a story which illustrates how a little boys IALAC is destroyed. The story is attached to the lesson plan.

5. After reading the story, the teacher will hand out a piece of paper and the students will be asked to make a IALAC sign of their own to wear for two days. Whenever somebody says or does something that hurts the students' IALAC, the student will tear a piece of his/her IALAC off. After two days the teacher and 
students will form a circle and discuss what happened to their IALAC signs.

6. After the students have spent two days with their IALAC signs on the instructor will ask the students the following questions:

- How did your IALAC sign get torn up?

-What things affected you the most?

- What did you do that destroyed the IALAC signs of others - in school, home?

- How did you feel when your IALAC sign was ripped?

- When you ripped someone else's IALAC sign how did you feel?

- What can we do to help people enlarge their signs rather than make them smaller?

7. At the end of the discuss everyone as a group will say : "no matter what you say or do to me, I'M STILL A WORTHWHILE PERSON!'

\section{IALAC STORY}

A fourth grade boy named Michael is lying in bed three minutes after his alarm goes off. All of a sudden his mother calls to him, Michael, you lazy-head, get your body out of bed and get down here before I send your father up there!" (rip) Michael gets out of bed, goes to get dressed, and can't find a clean pair of socks. His mother tells him he'll have to wear yesterdays pair. (rip) He goes to brush his teeth and his older sister, who's already locked herself in the bathroom, tells him to drop dead. (rip) He goes to breakfast to find soggy cereal waiting for him. (rip) As he leaves for school, he forgets his lunch and his mother calls to him, "Michael you've forgotten your lunch; you'd forget your head if it weren't attached!" (rip) As he gets to the corner he sees the school bus pull away and so he has to walk to school.(rip) He's late to school and has to get a pass from the principal who gives him a lecture. (rip) When he gets to recess some kind calls him a name. (rip) As he returns to class someone repeats the name and starts laughing at him. (rip) During lunch, Michael drops his tray and everyone claps. The day ends and Michael gets on the bus to go home, how do you think Michael feels and have you ever felt that way. 


\section{LESSON PLAN}

ACTIVITY: Things I like to do!

OBJECTIVE: To introduce the concept of goal setting to the students.

LENGTH OF LESSON: 30 to 40 minutes

D AYS: Monday, Wednesday or Friday

\section{PROCEDURES:}

1. Today we are going to be discussing things we like to do and goal setting.

2. Pass out $81 / 2$ "x11" lined folder paper to each student. Please write your name and write down twenty things you like to do.

3. After the students have completed their list they will transfer the things they like to do into categories on the things to do apple worksheet.

4. Hand-out apple worksheet and have the students place the things they like to do in the appropraite apple. There is an apple for things you do with a friend, things that cost money, things that you do often, you do by yourself and things you do once in a while.

5. After the students have completed their assignment have them bring their paper and a chair and form a circle so that we can discuss the assignment and have each student set a goal to do one thing they like to do, but haven't done in a long time. Check back with each student individually to see if they have accomplished their goal.

\section{MATERIALS:}

15 folder paper chairs

15 pencils

15 things I like to do worksheet 


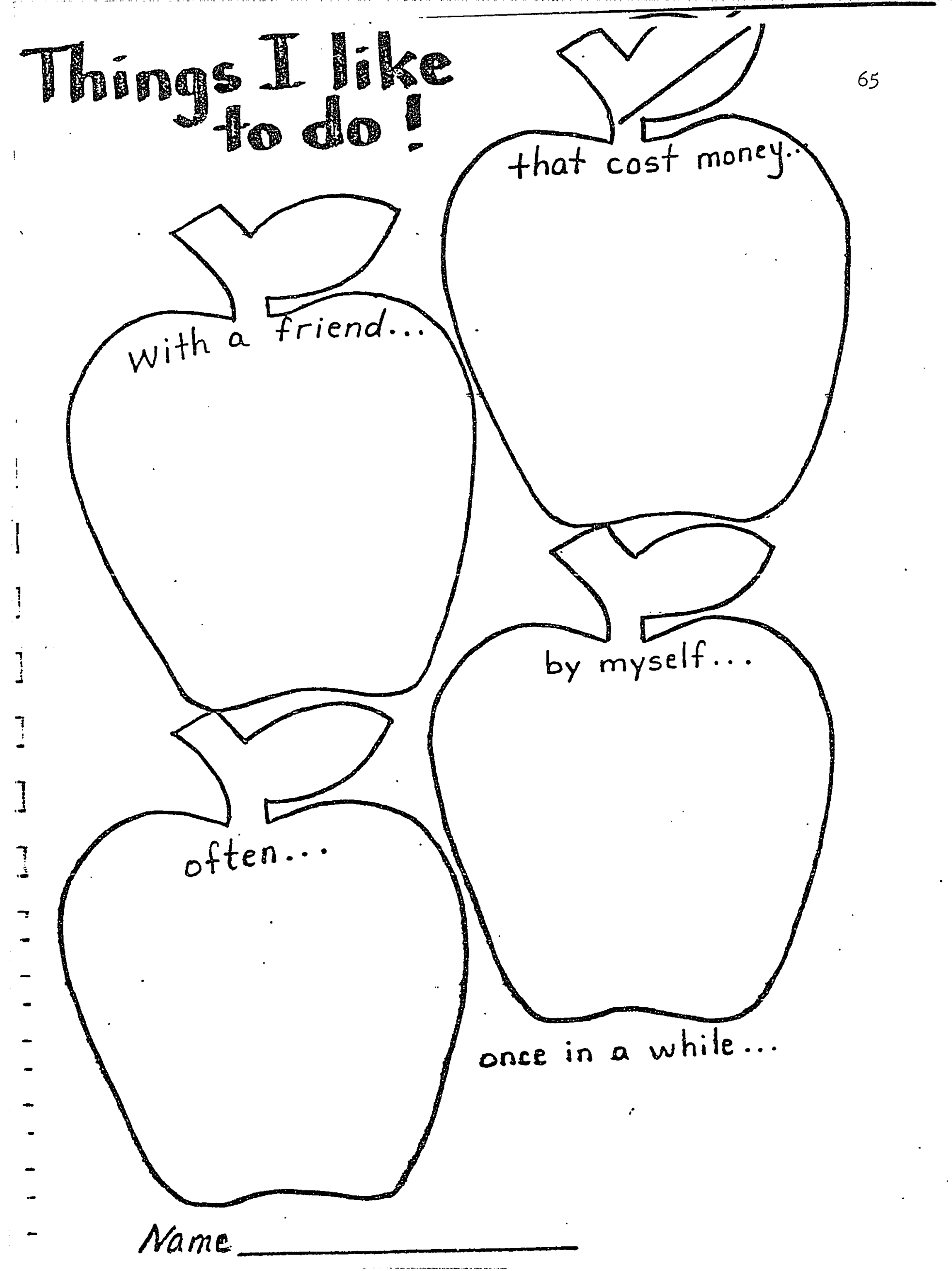




\section{LESSON PLAN}

ACTIVITY: Autobiographical Sharing

OBJECTIVE: To develop an environment of trust.

LENGTH OF LESSON: 30 to 40 minutes

DAYS: Monday, Wednesday, and Friday

PROCEDURES:

1. Students will be asked to formed a circle with their chairs.

2. Now that we've form the circle class, we will be sharing important experiences in our lives, where we were born and people who have leit a strong impression on you. Each of the students will have 45 seconds to a minute to talk abcut their experiences. The teacher will be the first person to share and then a coin will be tossed to determine who will go next. (Heads clockwise and tails counter clockwise). Those students who wish to pass may pass.

3. After everyone has shared, we will go around again. During the second turn the students will be asked if they would like to share something they remembered from the initial sharing.

4. Now that everyone has shared, the teacher will point out similarities that exist within the class.

\section{MATERIALS:}

chairs 


\section{LESSON PLAN}

\section{ACTIVITY: Four Drawings}

OBJECTIVE: To develop a sense of awareness about their inner selves.

LENGTH: 40 to 60 minutes

DAY: Monday, Wednesday or Friday

\section{PROCEDURES:}

1. Hand out a box of crayons and a large piece of white $81 / 2 \times 11$ construction paper to each student. Ask the students to divide the sheet into four sections. Explain to the siudents that they will be drawing four pictures illustrating the answers to the four questions will are going to be asking ourselves.

2. Have the students close their eyes and relax. Please clear your minds, you want to only hear your self. Next, tell them to imagine a blank movie screen in the middle of their forehead just above their nose. Tell them you are going to be giving them a question to ask themselves, and that they should image the answer projected onto their movie screen. As soon as the student(s) have seen their image have them open their eyes and draw the first image in the upper lefthand corner of the paper. The other images will be placed in the other remaining squares. Make sure that the pictures are numbered. The four questions are:

- Where am I?

- What obstacles will! face?

- What inner quality will I need to develop to overcome these obstacles?

3. Once all of the questions have been illustrated, ask the students to share them in groups of four.

\section{MATERIAL:}

$16-20$ boxes of crayons

$16-20$ pieces of white $81 / 2 \times 11$ construction paper 


\section{LESSON PLAN}

ACTIVITY: Autobiographical Questionnaires

OBJECTIVE: To help students expand their perceptions of themselves.

LENGTH OF LESSON: 30 to 40 minutes

DAYS: Monday, Wednesday and Friday

\section{PROCEDURES:}

1. The teacher will discuss with the students what autobiography means.

After the discussion the students will be asked to complete an autobiographical questionnaire.

2. The teacher will hand out the questionnaires to the students and tell them that the questions will be read aloud. If the students have any questions they are to raise their hand, and the teacher will provide them with assistance.

3. After all of the students have completed the questionnaires, the questionnaires will be collected by the teacher. The students will be told that at the end of this unit the questionnaires will be passed back to them for discussion. (We want to see if anything has changed since the first time the autobiographical questionnaire was completed).

\section{MATERIAL:}

Autobiographical questionnaire pencils 


\section{AUTOBIOGRAPHICAL QUESTIONNAIRE}

1. Name:

2. Birthdate:

3. Age

4. List five words that best describe you.

5. What do you see yourself doing five years from now?

6. What do you do after school and on weekends?

7. Who is your best friend? And what do your friends have in common?

8. What are your iavoritie sporìs, hobbies, or craíts, if any?

9. What is there about you that makes your friends like you?

10. What do you think of school?

11. Are you happy with yourself? Would you like to be better? Would you like help and advice in this respect? 
APPENDIX D 


\section{POSITIVE CUES}

good

great work

wonderful

awesome

fantastic

way to think

smile

looking good

Wow

right on

excellent

nice work

nice job

keep up the hard work

your right on track

great answer

high five

clap- round of applause

whoop, whoop, yaa!

super

superb

super work

thanks eye to eye

facing each other

nodding head

your welcome

Yes

alright

I like the way you...

look what a great job

you're special

that's unique

I can see you put alot of

thought into it

thanks for sharing

good listener 
APPENDIX E 
College of Education - Division of Special Education \& Rehabilitative Services

One Washington Square • San José, California 95192-0078 • 408/924-3700 • FAX 408/924-3713 • TDD 408/924-3701

\section{AGREEMENT TO PARTICIPATE IN RESEARCH SAN JOSE STATE UNIVERSITY}

RESPONSIBLE INVESTIGATOR: Deloislynn (Lynn) Boskie (Special Day Class Teacher at Rogers Elementary School in the Alum Rock School District)

TITTE OF PROTOCOL: Self-concept development program for learning disabled students in thiid through fifth grade. Your child is invited to participate in a research study that is investigating the effectiveness of a self-concept program. The results of this study should further our understanding of how to improve students with learning disabilities self-concept.

I understand that

1.) my child will be asked to participate in two self-concept inventories (a pretest and a posttest) and twelve lessons which will center on developing a positive self-concept. These scores will be compared to a group of students who will not be participating in the self-concept program.

2.) there are no anticipated risks in this study for my child.

3.) the possible benefits of this study to my child are he/she will be contributing to the development of a positive self-concept program.

4.) the results from this study may be published, but any information from this study that can be identified with my child will remain confidential and will be disclosed only with my permission.

5.) any questions about my child's participation in this study will be answered by Lynn Boskie at 258-3686. Complaints about the procedures may be presented to Dr. Gilbert Guerin at 924-3720; of Department of Special Education. For questions or complaints about research subjects's rights, or in the event of research-related injury, contact Serena Stanford, Ph.D. (Associate Academic Vice President for Graduate Studies \& Reseach) at 924-2480.

6.) my consent is given voluntarily without being coerced; my child may refuse to participate in this study or in any part of this study, and I may withdraw my consent at any time, without prejudice to my relations or my child's with SJSU and Alum Rock School District.

7.) I have received a copy of this consent form for my file.

HAVING READ THE INFORMATION PROVIDED ABOVE, I HAVE MADE A DECISION WHETHER OR NOT MY CHILD MAY PARTICIPATE. MY SIGNATURE INDICATES THAT MY CHILD MAY PARTICIPATE AND IS WILLING TO PARTICIPATE.

\section{DATE}

PARENT'S/GUARDIAN'S SIGNATURE
PRINT CHILD'S NAME 